\title{
Chemical, Microbiological and Sensory Profiles of Mixed Fruit Wine from Banana (Musa acuminata), Watermelon (Citrullus vulgaris L.), Pineapple (Ananas comoscus L.) and Cucumber (Cucumis sativus)
}

\section{Adeyemi Philips Adebowale*, Gabriel Olaniran Adegoke and Folasade Olabimpe Adeboyejo}

Department of Food Technology, University of Ibadan, Ibadan, Nigeria

*Corresponding Author: Adeyemi Philips Adebowale, Department of Food Technology, University of Ibadan, Ibadan, Oyo State, Nigeria.

DOI: $10.31080 /$ ASNH.2020.04.0637
Received: January 31, 2020

Published: February 07, 2020

(C) All rights are reserved by Adeyemi Philips

Adebowale., et al.

\begin{abstract}
Blend of several fruits (banana, pineapple, watermelon and cucumber) were used for producing wine. When it is realised that banana on its own may not really be suitable for wine production, however, addition of some fruits and Saccharomyces cerevisiae can be a source of obtaining acceptable wine. The aim of this work was to produce and improve the quality of banana wine by using blend that will be acceptable. Watermelon (Citrullus vulgaris L.), pineapple (Ananas comoscus L.) and cucumber (Cucumis sativus) musts (In ratio $60: 40$ and $100 \%$ as the control) were added respectively to banana must. Physico-chemical, antioxidants, colour, microbial, organic compounds and sensorial profiles of wine samples were done using standard methods. The $\mathrm{pH}$, volatile acidity and phenolics contents of the samples of wine ranged from 3.52 to $3.62,0.30$ to $0.60 \%, 602.76 \mathrm{mg}$ GAE/l to $858.51 \mathrm{mg}$ GAE/l respectively. Hue angles of the samples of wine were within $0-90^{\circ}$; from $57.45^{\circ}$ to $69.40^{\circ}$, and were significantly different $(\mathrm{p}<0.05)$ from each other. Colour of the wines was generally orange-red and microbiological examination of the samples showed no contamination with spoilage bacteria like acetobacter, pediococcus and gluconobacter species. Using Fourier Transform Infrared Spectroscopy (FTIR), the samples of wine were found to contain probable compounds like water, alcohol and esters. Principal Component Analysis (PCA) was useful in assessing the relationship and correlations of some of the parameters examined. In this study, blends rich in pineapple and watermelon were more acceptable to taste panelists than $100 \%$ banana wine. Our findings with this research work has shown that good quality mixed fruit wine can be produced using combination of banana and other fruits in right proportions.

Keywords: Fruits; Banana; Watermelon; Pineapple; Cucumber; Blend
\end{abstract}

\section{Introduction}

Apart from water and milk no other drink has universal acceptance and esteem throughout ages as wine [1]. The natural chemical balance of grape juice aids its fermentation into wine without the addition of sugars, acids, or other nutrients thus making grape to be a preferred fruit for wine production. Grapes are however not readily available and are also costly in some tropical regions [2]. Banana and other fruits can are used in the production of wine but due to the nature of banana fruit juice, it tends to affect its suitability for wine and this has led to use of enzymes (pectinase and $\alpha$-amylase) and recombinant yeast strains $[3,4]$. Producing wine from blends of fruits can provide good substrate for wine production [5]. When it is realised that banana juice contains high concentration of sugars and many acids, watermelon has beta carotene and lycopene, pineapple with its flavour and good source of sugar, ascorbic acid, cucumber with naturally-purified moisture content and high levels of flavonoids (apigenin, luteolin, quercitin, and kaempferol) and cucurbitacins - banana wine with all these nutrients from different fruits will improve its quality. Our present study was therefore carried out to ascertain the quality profiles and acceptability of wines produced from mixtures of banana and other fruits [6-10].

\section{Materials and Methods}

The study took place at the Department of Food Technology, University of Ibadan, Ibadan and National Horticultural Research Institute (NIHORT), Jericho, Ibadan, Nigeria between the months of May 2018 and December 2018.

\section{Collection of raw materials}

Ripe, mature and unbruised samples of banana (Musa acuminata), pineapple (Ananas comoscus L.), watermelon (Citrullus. vulgaris L.) and cucumber (Cucumis sativus) were purchased (June, 2018) in Ibadan, Nigeria and were identified as authentic samples at the National Horticultural Research Institute (NIHORT), Jericho, Ibadan, Nigeria before processing into wine. Commercial grade sugar (Dangote Sugar, Nigeria) and yeast were obtained locally. All chemicals and reagents used were of analytical grade. 


\section{Sample preparation}

Preparation of must and formulation

The fruits were washed with potable water and peeled, and juice extraction was carried out by homogenising the pulp in a blender (Scanfrost, SFKAB409, China) with distilled water (pulp; water, 1:1). To prevent browning and to inhibit unwanted microflora in the juice, $100 \mathrm{mg} / \mathrm{l}$ potassium metabisulphite was added. It was boiled at $80^{\circ} \mathrm{C}$ for $5 \mathrm{mins}$ and held overnight at room temperature for clarification. The musts obtained contained low sugar and it was chaptalised to $20^{\circ}$ brix with the aid table sugar and held at $\mathrm{pH}$ 4. The formulations used were modified from those used described elsewhere [11] and samples were coded as follows: sample 945 (banana $60 \%$ + pineapple $30 \%$ + watermelon $5 \%$ + cucumber $5 \%$ ), sample 238 (banana $60 \%+$ pineapple $5 \%+$ watermelon $5 \%$ + cucumber $30 \%$ ), sample 172 (banana $60 \%$ + pineapple $5 \%$ + watermelon $30 \%+$ cucumber $5 \%$ ), sample 561 (banana $60 \%+$ pineapple $13.3 \%$ + watermelon $13.3 \%$ + cucumber $13.3 \%$ ) and sample 476 (banana 100\%).

\section{Starter culture, fermentation and clarification}

Saccharomyces cerevisiae; active dry yeast, was activated in distilled water at $30^{\circ} \mathrm{C}$ and added to the must at a concentration of $3 \%$. After which fermentation was carried out at ambient temperature $\left(27^{\circ} \mathrm{C}\right)$ for 6 days with monitoring using the hydrometer until the reading reached 1.000-1.020. Secondary fermentation proceeded until all the sugars in the must were utilised completely. Thereafter, the 'young wines' were allowed to age for 4 months. Yeast and other materials that settled at the bottom of the container used for fermentation, were siphoned off or/racked, then 150 $\mathrm{ml}$ of prepared gelatin (10\%) was added into each of the wine container followed by stirring to dissolve properly. $100 \mathrm{ml}$ of the mixture was collected into a sterile bottle which was covered tightly and used to monitor the process of clarification. Filtration followed after the wines clarification: using muslin cloth, sieve and syphon tubes sterilised by $70 \%$ alcohol. The wines was syphoned into each sieve containing four layers of muslin cloth followed by pasteurisation and addition of potassium sorbate [1].

Determination of $\mathrm{pH}$, Total Titrable Acidity and Volatile Acidity $\mathrm{pH}$ was determined using a $\mathrm{pH}$ meter (HANNA Instruments, H12210-01, Benchtop, Rhode Island, USA).

Total Titrable Acidity (TTA) was determined by titrating $9 \mathrm{ml}$ of wine sample, against $0.1 \mathrm{~N}$ sodium hydroxide using phenolphthalein as an indicator and pink colour obtained marked the end point of titration with the percentage titratable acidity expressed as tartaric acid (milliequivalent, 0.075).

Volatile acidity was expressed as percentage acetic acid and was measured by steam distillation; $100 \mathrm{ml}$ of wine sample were boiled for 15 mins under reflux to expel carbon dioxide. The flask was cooled and the liquid steam-distilled to reduce the volume to $50 \mathrm{ml}$. This was titrated with $0.1 \mathrm{~N} \mathrm{NaOH}$ using 2 drops of phenolphthalein, $1 \mathrm{ml}$ of $\mathrm{NaOH}$ with the milliequivalent 0.006 of acetic acid [12].
Determination of total solids, soluble solids, alcohol content and temperature

Total solids and, specific gravity of each wine sample were carried out. Hand Held Digital Abbe refratometer (Wincom Company Limited, Pocket Type, Changsha, China) was used to determine the soluble solids of the wine blends samples according to Daramola and Asunni. The specific gravities of the wines were determined using the hydrometer method and the results were the reading stem which was used for alcohol content $[5,13]$.

Temperature of each wine sample was measured using mercury-in-glass thermometer [13].

$\% A B V=\frac{\text { Initial Sg }- \text { Final Sg }}{7.37} \times 100$

\section{Antioxidative potentials analyses}

Determination of free racial scavenging

Free radical scavenging ability of the wine extract against DPPH (1, 1- diphenyl-2-picryhydrazyl) was determined. $1 \mathrm{ml}$ of the extract to was mixed with $1 \mathrm{ml}$ of $0.4 \mathrm{mM}$ methanolic solution of DPPH (SigmaAldrich) [14]. The mixture was left in the dark for 30 min and thereafter absorbance of the mixture measured at $516 \mathrm{~nm}$. The percentage inhibition was calculated as a percentage of DPPH discolouration using the equation:

$\%$ Inhibition $=[(\mathrm{ADPPH}-\mathrm{AS}) / \mathrm{ADPPH}] \times 100$

Where, AS is the absorbance of the solution when the sample extract has been added at a particular level and ADPPH is the absorbance of the DPPH solution.

\section{Determination of reducing antioxidant property}

Reducing property of wine extract was determined using method described elsewhere [15]. $0.25 \mathrm{ml}$ of the wine extract was mixed with $0.25 \mathrm{ml}$ of $200 \mathrm{mM}$ of sodium phosphate buffer $\mathrm{pH} 6.6$ and $0.25 \mathrm{ml}$ of $1 \%$ potassium ferric cyanide. The mixture was incubated at $50^{\circ} \mathrm{C}$ for $20 \mathrm{~min}$, after which $0.25 \mathrm{ml}$ of $10 \%$ trichloroacetic acid (TCA) was also added and centrifuged at $2000 \mathrm{rpm}$ for $10 \mathrm{~min}, 1 \mathrm{ml}$ of the supernatant was mixed with $1 \mathrm{ml}$ of distilled water and $0.1 \%$ of $\mathrm{FeCl}_{3}$ and the absorbance was measured at $700 \mathrm{~nm}$ in a spectrophotometer (GENESYS 10SVis, Thermo Scientific, city, USA). Ferric reducing antioxidant power (FRAP) values were obtained by comparing the absorption change in the test mixture with those obtained from increasing concentrations of $\mathrm{Fe}^{2+}$, and expressed as mmol of $\mathrm{Fe}^{2+}$ equivalents per litre of sample.

\section{Determination of scavenging ability}

2, 2'-azino-bis (3-ethylbenthiazoline-6-sulphonic acid) (ABTS) scavenging ability of what the wine extract was determined according to the method described by Re., et al. [16]. ABTS in full here was generated by reacting ABTS stock solution $(7 \mathrm{mM})$ with $2.45 \mathrm{mM}$ $\mathrm{K}_{2} \mathrm{~S}_{2} \mathrm{O}_{8}(1 / 1, v / v)$ in the dark for 16 hours until the reaction was completed and the absorbance was stable. The (ABTS) solution was diluted with ethanol to an absorbance of $0.700 \pm 0.05$ at $734 \mathrm{~nm}$ for measurements. Thereafter, $0.2 \mathrm{ml}$ of the appropriate dilution of the 
wine extract was then added to $2.0 \mathrm{ml}$ of ABTS solution and mixed for $45 \mathrm{sec}$; and the absorbance was read at 732nm after 15 mins. The trolox equivalent antioxidant capacity was subsequently calculated (264.32g). The results were expressed as mmol of Trolox per litre of the sample.

\section{Determination of total phenolic content}

The Total Phenolic Content of the extract was determined using the method described by Singleton [17]. $0.2 \mathrm{ml}$ of the extract was mixed with $2.5 \mathrm{ml}$ of $10 \%$ Folin ciocalteau's reagent (Merck, Darnstadt, Germany) and $2 \mathrm{ml}$ of $7.5 \%$ sodium carbonate. The reaction mixture was subsequently incubated at $45^{\circ} \mathrm{C}$ for 40 mins, and the absorbance was measured at 700nm using a spectrophotometer-Gallic acid was used as the standard and data obtained were expressed as milligram of Gallic Acid Equivalents (GAE) per litre of extract.

\section{Determination of Total Flavonoid Content}

Total flavonoid content of the extract was determined using a colourimeter assay developed by Bao [18]. $0.2 \mathrm{ml}$ of the extract was added to $0.3 \mathrm{ml}$ of $5 \% \mathrm{NaNO}_{3}$ at zero time. After $5 \mathrm{mins}, 0.6$ $\mathrm{ml}$ of $10 \% \mathrm{AlCl}_{3}$ was added and after $6 \mathrm{~min}, 2 \mathrm{ml}$ of $1 \mathrm{M} \mathrm{NaOH}$ was added to the mixture followed by the addition of $2.1 \mathrm{ml}$ of distilled water. Absorbance was read at $510 \mathrm{~nm}$ against the reagent blank and flavonoid content was expressed as mg catechin equivalent.

\section{Determination of tannin}

Tannin determination was done according to the method described by AOAC with some modifications: $1 \mathrm{ml}$ of the wine extract was filtered into $100 \mathrm{ml}$ volumetric flask, followed by the addition of $20 \mathrm{ml}$ of distilled water, $2.5 \mathrm{ml}$ of Folin-Denis reagent and 10 $\mathrm{ml}$ of $17 \%$ aqueous. $\mathrm{Na}_{2} \mathrm{CO}_{3}$ was also added and thoroughly mixed together. The mixture was then made up to $100 \mathrm{ml}$ with distilled water, mixed and allowed to stand for 20 mins. The bluish-green colour developed at the end of the reaction mixture of different concentrations ranging from $10-50 \mathrm{ppm}$. The absorbance of the tannic acid standard solutions as well as sample was measured after colour development at 760 nm using spectrophotometer AJI$\mathrm{CO}_{3}$ UV-VIS [12].

\section{Colour determination}

Colour $\left(\mathrm{L}^{*} \mathrm{a}\right.$ b) parameters were determined using the colourimeter (Colour Tec PCMTM Colour Tec Associates, Inc., Clinton, NJ, USA). L, a, and b parameters were determined by placing the sensor of the colourimeter on the sample (19). From the data obtained, the following parameters were also derived:

Hue angle $=$ Tan-1 $(\mathrm{b} / \mathrm{a})$

Whiteness Index $(\mathrm{WI})=100-[(100-L *) 2+(\mathrm{a} *) 2+(\mathrm{b} *) 2] 0.5$

Yellowness Index $(\mathrm{YI})=142.86 \mathrm{~b}^{*} / \mathrm{L}^{*}$

Chroma $=[(\mathrm{a} *) 2+(\mathrm{b} *) 2] 0.5$
Colour difference $\Delta \mathrm{E}^{*}=\left[\Delta \mathrm{a}^{*} \Delta \mathrm{b}^{*} \Delta \mathrm{c}^{*}\right] 0.5$

\section{Sensory evaluation}

Sensory evaluation was carried out by a panel of 20 semitrained panelists from Food Technology Department, University of Ibadan and National Horticulture Research Institute, Ibadan, Nigeria. Each member compared wines for colour, flavour, taste, clarity, and overall acceptability on 9-point hedonic scale where 9 denotes excellent and 1 very poor.

The sensory evaluation procedure was modified as described by Ogodo, Ugbogus, and Ezeonu and the exercise was carried out on the second day of wine production [11].

\section{Microbiological analysis}

Microflora of different blends was determined using Potato Dextrose Agar, Nutrient Agar, MacConkey Agar, de Man, Rogosa Sharpe and Carr Medium as described elsewhere [20,21].

Fourier transform infrared spectroscopy (FTIR) analysis

The wines were subjected to IR spectroscopy (Shimadzu, Japan). The infrared analysis of the wine was carried using Nujol as the sample holder, operated in a wavelength range of 4000-500 $\mathrm{cm}^{-1}$ using FT-IR 8300 series [12].

\section{Statistical analyses}

Data obtained from samples analysed in triplicates were subjected to analysis of variance (ANOVA) and Duncan's multiple range test using the Statistical Package for the Social Sciences (SPSS) version 20.0 software (SPSS Inc., Chicago, IL, USA); ${ }^{* *} \mathrm{P}<0.05$ was considered statistically significant; reported results are expressed as the Mean \pm SD. Principal Component Analysis by XLSTAT version 2018.7 (Addinsoft, U.S.A).

\section{Results}

The physico-chemical properties of wines examined in this study are shown in Table 1. $\mathrm{pH}$ values in the mixed wines which were in the range of $3.10 \sim 3.60$ were acidic throughout the period of fermentation. Values for total titrable acidity (TTA) were between $0.60 \sim 0.82 \%$, with samples 945 and 172 being more was acidic with no significant difference ( $p>0.05$ ). However, sample 945 had the highest volatile acidity of $0.66 \%$.

The percentage alcohol in the wines at the end of fermentation were $11 \%(\mathrm{v} / \mathrm{v})$ for samples 476 and 561 while samples 172, 238 and 945 had 12\% (v/v) respectively. Total soluble solids (TSS) values ranged from 3.2 4.9 after the fermentation stopped. Temperature of the final mixed wines ranged from $20.7^{\circ} \mathrm{C}$ to $23.1^{\circ} \mathrm{C}$. The antioxidative assays (Tables 2,3) were as follows (Table 2 and Table 3). DPPH assay in the samples was in the decreasing order sample 945 (80.70\% Ihb) > sample 172 (78.26\% Ihb) > sample 238 (64.99\% Ihb) > sample 561 (62.05\% Ihb) > sample 476 (55.67\% Ihb) correlating with other methods used to determine antioxidative potential; Ferric Reducing Property (FRAP) and Trolox Equivalent Antioxidant Capacity (TEAC). Total Phenols in the wine samples increased in order of $602.76 \mathrm{mg} \mathrm{GAE} / \mathrm{l} \sim 858.51 \mathrm{mg}$ GAE/l) 


\begin{tabular}{|l|c|c|c|c|c|c|c|}
\hline Wine & $\mathbf{p H}$ & $\mathbf{T T A \%}$ & $\begin{array}{c}\text { Volatile Acidity } \\
\mathbf{\%}\end{array}$ & $\mathbf{A B V}(\mathbf{\%})$ & $\begin{array}{c}\text { Total Soluble Solids } \\
\mathbf{(} \mathbf{B})\end{array}$ & $\begin{array}{c}\text { Total Solids } \\
\mathbf{( \% )}\end{array}$ & $\begin{array}{c}\text { FermentationTemperature } \\
\left(\mathbf{}^{\mathbf{0}} \mathbf{C}\right)\end{array}$ \\
\hline 238 & $3.57^{\mathrm{b}} \pm 0.01$ & $0.64^{\mathrm{b}} \pm 0.02$ & $0.46^{\mathrm{b}} \pm 0.01$ & 12 & 3.2 & $2.40^{\mathrm{c}} \pm 0.02$ & $21.3 \pm 1.2$ \\
\hline 561 & $3.60^{\mathrm{a}} \pm 0.01$ & $0.60^{\mathrm{b}} \pm 0.02$ & $0.35^{\mathrm{d}} \pm 0.02$ & 11 & 4.7 & $2.95^{\mathrm{b}} \pm 0.01$ & $20.4 \pm 1.3$ \\
\hline 172 & $3.53^{\mathrm{c}} \pm 0.02$ & $0.78^{\mathrm{a}} \pm 0.03$ & $0.64^{\mathrm{a}} \pm 0.01$ & 12 & 3.9 & $2.42^{\mathrm{c}} \pm 0.01$ & $23.1 \pm 1.5$ \\
\hline 945 & $3.52^{\mathrm{c}} \pm 0.01$ & $0.82^{\mathrm{a}} \pm 0.03$ & $0.66^{\mathrm{a}} \pm 0.02$ & 12 & 3.7 & $2.35^{\mathrm{d}} \pm 0.01$ & $22.3 \pm 1.7$ \\
\hline 476 & $3.62^{\mathrm{a}} \pm 0.02$ & $0.62^{\mathrm{b}} \pm 0.01$ & $0.42^{\mathrm{c}} \pm 0.01$ & 11 & 4.9 & $3.09^{\mathrm{a}} \pm 0.01$ & $20.7 \pm 0.8$ \\
\hline
\end{tabular}

Table 1: Physico-Chemical properties of the wines.

Values are mean \pm SD of 3 replicates. Different letters (a-e) within same row are significantly different $(\mathrm{P}<0.05)$ according to Duncan's multiple range test. $238:(60+5+5+30) \%$, 561: $(60+13.3+13.3+13.3) \%, 172:(60+5+30+5) \%, 945:(60+30+5+5) \%, 476:(100 \%)$.

which follows the same pattern with tannins. Sample $172 \mathrm{had}$ the highest amount of tannin (128 mg/l) while sample $561(90.42$ $\mathrm{mg} / \mathrm{l})$ had the least amount of tannins. It was also evident from the colour analysis, a* redness to greenness level of the sample, highest a* value was observed in sample 172. The results of hue angles (E.q 2.3) for the blends fell within $0-90^{\circ}$; from $57.45^{\circ}$ to $69.40^{\circ}$.
Acceptability of the wines as were as follows: sample $945>$ sample $172>$ sample $238>$ sample $561>$ sample 476 (Table 4). There were no significant differences in the microbial loads in the of samples 172, 238 and 945 but these samples were significantly different to sample 561 and no growth was observed in sample 476 (Table 5).

\begin{tabular}{|c|c|c|c|c|c|c|}
\hline Wine & DPPH (\%Ihb) & $\begin{array}{c}\text { TEAC }^{1} \\
\text { (mMolTrolox/l) }\end{array}$ & FRAP $^{2}\left(\mathrm{mMolFe}^{2+} / \mathrm{l}\right)$ & $\begin{array}{l}\text { Phenols }^{3} \\
\text { (mgGAE/l) }\end{array}$ & $\begin{array}{l}\text { Flavonoids }^{4} \\
\text { (mg/l) }\end{array}$ & Tannin (mg/l) \\
\hline 238 & $64.99^{\mathrm{b}} \pm 1.91$ & $49.62^{\mathrm{c}} \pm 1.39$ & $44.80^{c} \pm 1.00$ & $730.35^{c} \pm 18.9$ & $309.44^{c} \pm 25.0$ & $109.55^{c} \pm 2.76$ \\
\hline 561 & $62.05^{c} \pm 0.93$ & $42.84^{\mathrm{d}} \pm 1.72$ & $20.70^{\mathrm{d}} \pm 2.10$ & $602.76^{\mathrm{e}} \pm 2.3$ & $476.11^{b} \pm 13.89$ & $90.42^{\mathrm{b}} \pm 0.34$ \\
\hline 172 & $78.26^{a} \pm 0.91$ & $62.50^{\mathrm{b}} \pm 1.17$ & $50.61^{\mathrm{b}} \pm 1.10$ & $858.51^{\mathrm{a}} \pm 29.31$ & $509.45^{\mathrm{a}} \pm 8.33$ & $128.78^{\mathrm{a}} \pm 4.39$ \\
\hline 945 & $80.70^{\mathrm{a}} \pm 1.36$ & $86.39^{\mathrm{a}} \pm 1.27$ & $69.11^{\mathrm{a}} \pm 1.11$ & $786.10^{\mathrm{b}} \pm 2.87$ & $312.23^{c} \pm 5.56$ & $117.91^{\mathrm{c}} \pm 0.37$ \\
\hline 476 & $55.67^{\mathrm{d}} \pm 1.45$ & $38.62^{\mathrm{e}} \pm 1.94$ & $19.40^{\mathrm{e}} \pm 1.00$ & $634.37^{\mathrm{d}} \pm 0.58$ & $245.56^{\mathrm{d}} \pm 5.55$ & $95.16^{d} \pm 0.09$ \\
\hline
\end{tabular}

Table 2: Antioxidants properties of the wines.

Values are mean \pm SD of 3 replicates. Different letters (a-e) within same row are significantly different $(\mathrm{P}<0.05)$ according to Duncan's multiple range test. ${ }^{1}$ FRAP: Ferric reducing antioxidant power. ${ }^{2}$ TEAC: Trolox equivalent antioxidant activity ${ }^{3}$ GAE: gallic acid equivalent. ${ }^{4}$ Cat: Catechin equivalent. 238: $(60+5+5+30) \%$, 561: $(60+13.3+13.3+13.3) \%, 172:(60+5+30+5) \%, 945:(60+30+5+5) \%, 476$ :

$(100+0+0+0)$.

\begin{tabular}{|l|c|c|c|c|c|c|c|c|}
\hline Wine & $\mathbf{L}^{*}$ & $\mathbf{a}^{*}$ & $\mathbf{b}^{*}$ & $\mathbf{h}^{*}$ & $\mathbf{C}^{*}$ & $\mathbf{W I}$ & YI & \multicolumn{1}{|c|}{$\mathbf{E}^{*}$} \\
\hline 238 & $50.57^{\mathrm{c}} \pm 0.7$ & $-3.50^{\mathrm{e}} \pm 0.02$ & $9.58^{\mathrm{c}} \pm 0.06$ & $69.93^{\mathrm{a}} \pm 0.05$ & $10.19^{\mathrm{d}} \pm 0.01$ & $49.52^{\mathrm{c}} \pm 0.03$ & $27.06^{\mathrm{c}} \pm 0.10$ & $23.13^{\mathrm{c}} \pm 0.08$ \\
\hline 561 & $48.63^{\mathrm{d}} \pm 0.4$ & $-5.19^{\mathrm{d}} \pm 0.06$ & $8.13^{\mathrm{e}} \pm 0.26$ & $57.45^{\mathrm{e}} \pm 0.27$ & $9.65^{\mathrm{e}} \pm 0.02$ & $47.73^{\mathrm{d}} \pm 0.08$ & $23.88^{\mathrm{d}} \pm 0.30$ & $21.96^{\mathrm{d}} \pm 0.19$ \\
\hline 172 & $59.56^{\mathrm{a}} \pm 0.0$ & $5.44^{\mathrm{c}} \pm 0.01$ & $9.20^{\mathrm{d}} \pm 0.05$ & $59.40^{\mathrm{d}} \pm 0.08$ & $10.69^{\mathrm{c}} \pm 0.01$ & $58.17^{\mathrm{a}} \pm 0.01$ & $22.07^{\mathrm{e}} \pm 0.02$ & $31.97^{\mathrm{a}} \pm 0.02$ \\
\hline 945 & $56.01^{\mathrm{b}} \pm 0.1$ & $-6.27^{\mathrm{a}} \pm 0.11$ & $11.15^{\mathrm{b}} \pm 0.18$ & $60.64^{\mathrm{c}} \pm 0.09$ & $12.79^{\mathrm{b}} \pm 0.02$ & $54.19^{\mathrm{b}} \pm 0.06$ & $28.44^{\mathrm{b}} \pm 0.13$ & $28.74^{\mathrm{b}} \pm 0.14$ \\
\hline 476 & $47.12^{\mathrm{e}} \pm 0.1$ & $-5.71^{\mathrm{b}} \pm 0.01$ & $13.23^{\mathrm{a}} \pm 0.01$ & $66.65^{\mathrm{b}} \pm 0.01$ & $14.4^{\mathrm{a}} \pm 0.02$ & $45.19^{\mathrm{e}} \pm 0.07$ & $40.11^{\mathrm{a}} \pm 0.01$ & $20.45^{\mathrm{e}} \pm 0.06$ \\
\hline
\end{tabular}

Table 3: Colour determination of the wines.

Values are mean \pm SD of 3 replicates. Different letters (a-e) within same row are significantly different $(\mathrm{P}<0.05)$ according to Duncan's multiple range test. $L^{*}$ : Lightness; $\mathrm{a}^{*}$ : red (+)/green (-); $\mathrm{b}^{*}$ : yellow (+)/blue (); $\mathrm{C}^{*}$ : Chroma; $\Delta \mathrm{E}^{*}$ : Total colour difference; $\mathrm{h}^{*}$ : Hue angle; WI: Whiteness Index; YI: Yellowness Index. 238: $(60+5+5+30) \%$, 561: $(60+13.3+13.3+13.3) \%, 172:(60+5+30+5) \%, 945$ : $(60+30+5+5) \%, 476:(100+0+0+0) \%$.

\begin{tabular}{|l|c|c|c|c|c|}
\hline Wine & Taste & Aroma & Colour & Clarity & Overall A. \\
\hline 238 & $6.96^{\mathrm{a}} \pm 1.50$ & $6.00^{\mathrm{b}} \pm 1.60$ & $7.04^{\mathrm{ab}} \pm 1.68$ & $6.62^{\mathrm{ab}} \pm 1.33$ & $6.8^{\mathrm{ab}} \pm 1.02$ \\
\hline 561 & $6.81^{\mathrm{a}} \pm 0.90$ & $6.38^{\mathrm{ab}} \pm 1.65$ & $6.27^{\mathrm{bc}} \pm 1.66$ & $6.46^{\mathrm{ab}} \pm 1.24$ & $6.46^{\mathrm{bc}} \pm 1.30$ \\
\hline 172 & $6.30^{\mathrm{a}} \pm 1.67$ & $7.00^{\mathrm{a}} \pm 1.50$ & $7.27^{\mathrm{a}} \pm 1.43$ & $7.00^{\mathrm{a}} \pm 1.01$ & $7.03^{\mathrm{a}} \pm 1.31$ \\
\hline 945 & $6.40^{\mathrm{a}} \pm 1.77$ & $7.19^{\mathrm{a}} \pm 1.09$ & $7.70^{\mathrm{a}} \pm 0.96$ & $6.96^{\mathrm{a}} \pm 1.92$ & $7.46^{\mathrm{a}} \pm 0.99$ \\
\hline 476 & $6.90^{\mathrm{a}} \pm 1.30$ & $5.5^{\mathrm{b}} \pm 1.80$ & $5.62^{\mathrm{c}} \pm 1.50$ & $5.84^{\mathrm{b}} \pm 1.95$ & $6.00^{\mathrm{c}} \pm 1.64$ \\
\hline
\end{tabular}

Table 4: Sensory evaluation of the wines.

Values are mean \pm SD of 3 replicates. Different letters (a-e) within same row are significantly different $(\mathrm{P}<0.05)$ according to Duncan's multiple range test. $238:(60+5+5+30) \%, 561:(60+13.3+13.3+13.3) \%, 172:(60+5+30+5) \%, 945:(60+30+5+5) \%, 476:(100 \%)$. 
Chemical, Microbiological and Sensory Profiles of Mixed Fruit Wine from Banana (Musa acuminata), Watermelon (Citrullus vulgaris L.), Pineapple (Ananas comoscus L.) and Cucumber (Cucumis sativus)

\begin{tabular}{|l|c|c|c|c|c|}
\hline Wine & NA (cfu/ml) & PDA (cfu/ml) & MCA (cfu/ml) & CAR (cfu/ml) & MRS (cfu/ml) \\
\hline 238 & NG & NG & NG & $2.1 \times 10^{1 \mathrm{a}} \pm 10$ & NG \\
\hline 561 & NG & $2.4 \times 10^{3 \mathrm{~b}} \pm 200$ & NG & $1.1 \times 10^{1 \mathrm{~b}} \pm 10$ & NG \\
\hline 172 & NG & NG & NG & $2.1 \times 10^{1 \mathrm{a}} \pm 10$ & $2.13 \times 10^{1 \mathrm{a}} \pm 30$ \\
\hline 945 & NG & NG & NG & $2.0 \times 10^{1 \mathrm{a}} \pm 10$ & $1.10 \times 10^{1 \mathrm{~b}} \pm 20$ \\
\hline 476 & NG & $7 \times 10^{3 \mathrm{a}} \pm 200$ & NG & NG & NG \\
\hline
\end{tabular}

Table 5: Microbial analysis of the wines.

Values are mean \pm SD of 3 replicates. Different letters (significantly different $(\mathrm{P}<0.05)$ according to Duncan's multiple range test. NA: Nutrient Agar; PDA: Potato Dextrose Agar; MCA: MarConkey Agar; CAR: Car medium; MRS: de Man, Rogosa Sharpe; NG: No Growth. 238: $(60+5+5+30) \%$, 561: $(60+13.3+13.3+13.3) \%, 172:(60+5+30+5) \%, 945:(60+30+5+5) \%, 476:(100+0+0+0) \%$.

Fourier Transform Infrared results of the wines; provided the functional groups of the organic compounds present in the samples. The organic compounds were: hydroxyl and carboxylic acids (O-H) - 3300-3600 $\mathrm{cm}^{-1}$, esters (C-O) - 1000-1300 $\mathrm{cm}^{-1}$ (2 bands) $\mathrm{cm}^{-1}$, ether (C-0) - 1050-1200 $\mathrm{cm}^{-1}$, and 1070-1150 $\mathrm{cm}^{-1}$, amines (NH2 and N-H, C-N, NH2, and N-H) - 600-900 cm-1 , 1000-1250 cm1, 1550-1650 $\mathrm{cm}^{-1}$, and 3300-3500 $\mathrm{cm}^{-1}$ (Figures 1(a)-(e)).
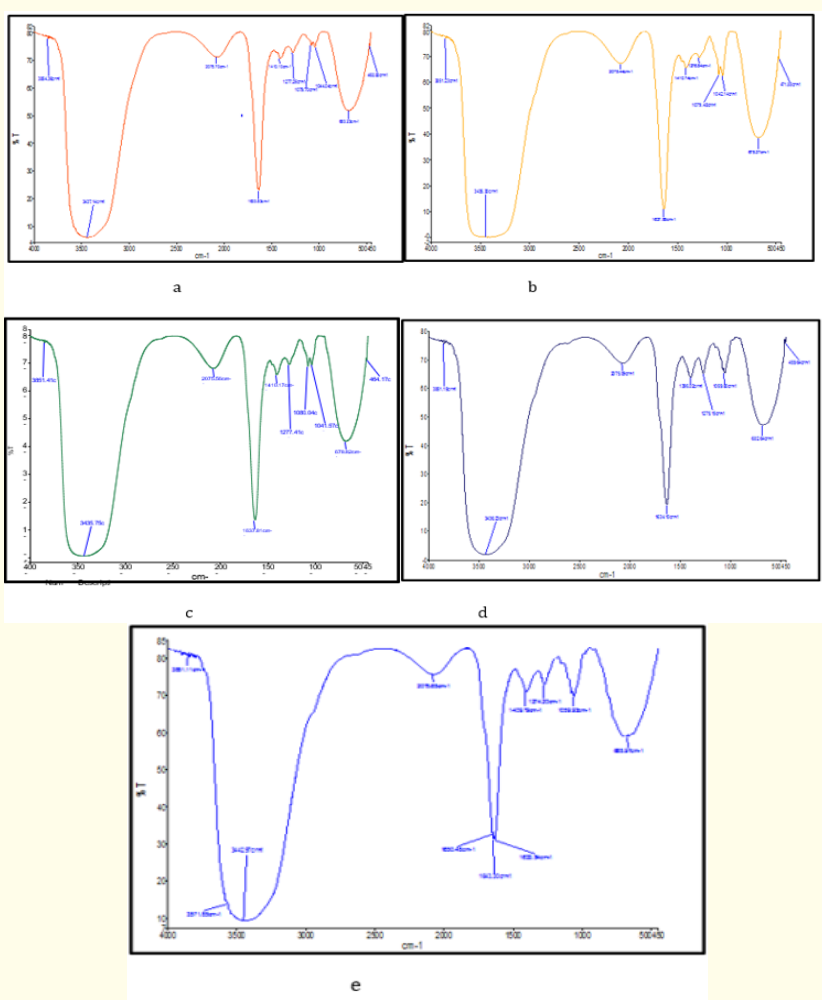

Figure 1a: IR Spectrum of Sample 238.

(banana $60 \%$ + pineapple $5 \%$ + watermelon $5 \%$ + cucumber $30 \%$ ).

Figure 1b: IR Spectrum of Sample 561.

(banana 60\% + pineapple $13.3 \%$ + watermelon $13.3 \%$ + cucumber $13.3 \%$ ).

Figure 1c: IR Spectrum of Sample 172.

(banana $60 \%$ + pineapple 5\% + watermelon 30\% + cucumber $5 \%$ ).

Figure 1d: IR Spectrum of Sample 945.

(banana 60\% + pineapple 30\% + watermelon $5 \%$ + cucumber $5 \%$ ).

Figure 1e: IR Spectrum of Sample 476. (banana 100\%).
Using principal component analysis for the wines and their quality - was employed. Samples 172 and 945 were on one side of the plot while samples 238, 561 and 476 were on the other side (Figures 2 and 3). Principal Component Analysis permits visual interpretation of the data represented by two-dimensional scatter plots $[22,23]$.

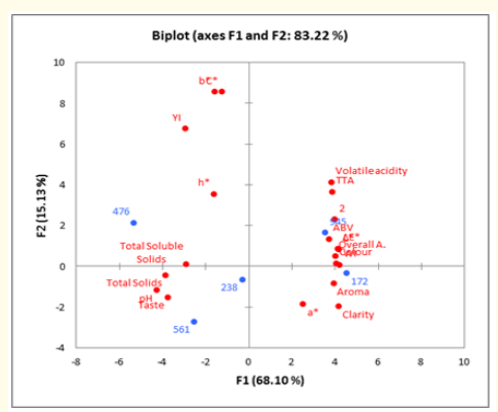

Figure 2: Principal Component Analysis (PCA), Biplot (a) for factor 1 and factor 2; sample 945 (banana $60 \%$ + pineapple $30 \%$ + watermelon 5\% + cucumber 5\%), sample 238 (banana $60 \%+$ pineapple $5 \%$ + watermelon $5 \%$ + cucumber $30 \%$ ), sample 172 (banana $60 \%$ + pineapple $5 \%$ + watermelon $30 \%+$ cucumber $5 \%$ ), sample 561 (banana 60\% + pineapple 13.3\% + watermelon 13.3\% + cucumber 13.3\%). sample 476 (banana 100\%). TTA: Total Titrable Acidity; $a^{*}$ : Greenness-redness Index; $h^{*}$ : Hue angle; YI: Yellowness Index; $\mathrm{C}^{*}$ : Chroma; $\Delta \mathrm{E}^{*}$ : Total Colour Difference; ABV: Alcohol by Volume.

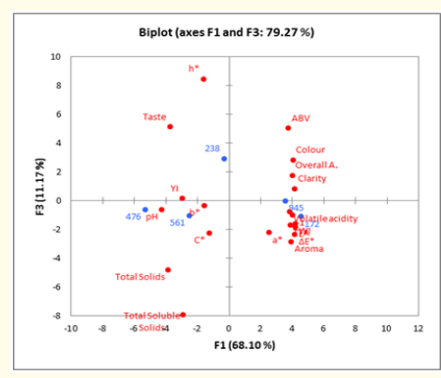

Figure 3: Principal Component Analysis (PCA), Biplot (b) for factor 1 and factor 3 ; sample 945 (banana $60 \%$ + pineapple $30 \%$ + watermelon $5 \%$ + cucumber $5 \%$ ), sample 238 (banana $60 \%+$ pineapple $5 \%+$ watermelon $5 \%+$ cucumber $30 \%$ ), sample 172 (banana $60 \%$ + pineapple $5 \%$ + watermelon $30 \%$ + cucumber $5 \%$ ), sample 561 (banana $60 \%$ + pineapple $13.3 \%$ + watermelon $13.3 \%$ + cucumber 13.3\%). sample 476 (banana 100\%). TTA: Total Titrable Acidity; $a^{*}$ : Greenness-redness Index; $h^{*}$ : Hue Angle; YI: Yellowness Index; $\mathrm{C}^{*}$ : Chroma; $\Delta \mathrm{E}^{*}$ : Total Colour Difference; ABV: Alcohol by Volume. 


\section{Discussion}

In this study, changes in $\mathrm{pH}$ of wines (Table 1) which were similar to the ones reported for banana wine elsewhere could be due to the production of acids within the period of fermentation probably arising from microbial succession $[24,25]$. When it is realised that increase in acidity of the samples of wine examined in this study could be due to accumulation of organic acids during fermentation low $\mathrm{pH}$ of the wine samples protected them against microbial spoilage and also produced at the same time more rapid natural clarification with greater effectiveness of stabilisation treatments and a longer shelf life [26]. In this work, the concentrations of ethanol contributed to the whole characteristic quality and flavour of the wine produced [27]. Total solids of the wines examined in this study were low; low values of total solids can however be attributed to the efficiency of yeasts used for fermentation.

Temperature is one of the most important parameters in oenology because it influences the fermentation kinetics and the chemical quality of wine [26]. During the period of fermentation there were fluctuations in the temperature, however, wine fermentation should be between $13-35^{\circ} \mathrm{C}[28]$. The observed changes in the temperature of the wines could wines could be due to microbial succession arising from microbial metabolic activities [29]. Bacteria have both positive and negative influences on wine production. From the morphological examination and biochemical tests done, the samples are not colonised with spoilage bacteria like pediococcus, acetobacter and gluconobacter: invariably, this shows that the wine has not been spoilt; the differences in microbial loads could be due to differences in the fruit wine blends.

Wines are healthy beverages that have been used as natural remedy for man's illness from early days [29]. In evaluating the antioxidative of any food product; it is essential to use at least three radical, as the solvent and substrate do impact on the values obtained [30]. Sun., et al. have also proved the influence of pineapple in scavenging free radical through DPPH assay [31]. Besides, watermelon in the work of Melo., et al. showed remarkable free radical scavenging and antioxidant activity` owing to potent antioxidant lycopene [32]. According to Gawel, tannins are polymeric flavonoid compounds containing subunits of flavan-3-ol, responsible for colour stability, astringency and active antioxidants-results for flavonoids shows positive correlation while sample 476 (245.56 mg Cat/l) had the least amount of flavonoids [33]. And also the intensity of the sample $\mathrm{a}^{*}$ could be indication of concentration level of lycopene, while sample 476 had the highest level of yellowness index (E.q 2.5) due to the level of high concentration of the banana which was $100 \%$, which implies orange-red colouration. The most whitish sample was 945 and the least was sample 476, while samples 172 and 945 had the highest $L^{*}$ value of 59.56 and 56.01 respectively, this could be due to the low $\mathrm{pH}$ as reported by Ribereau-Gayon [26].

With respect to the sensory analysis of the samples of wine examined in this present study, the mean scores for overall acceptability showed no significant difference between samples 172, 238 and 945 meaning that the samples were equally accepted while samples 476 and 561 were significantly different ( $p>0.05)$.

From the FTIR spectra (Figures 1(a)-(e)), the hydroxyl group in the wine sample was confirmed to be phenolics-Phenolics have one phenol group (at least one hydroxylated benzene ring), and the other more complex phenol group that probable to be present is flavonoids likewise tannins: which are complex esters of glucose and gallic acid.

From the analysis carried out with PCA for the physico-chemical properties, colour determination and sensory characteristics-the closeness of each of the parameters show their relationship; Also, these might be important in defining the acceptability of samples 172 and 945-alcohol, colour, volatile acidity, total titrable acidity clarity, aroma, whiteness index, colour difference and lightness index have appeared to be positively correlated owing from results. Thus, the different blends of the fruit in each fruit wine led to the differences and most importantly the acceptability of samples 172 and 945 . Better still, the samples also have shown to be better in terms of antioxidant properties.

\section{Conclusion}

Mixed fruit wine was produced from blending of banana, pineapple, watermelon and cucumber musts. From the results of this present study; fruit wine from appropriate levels of banana $60 \%+$ pineapple $30 \%$ + watermelon $5 \%$ + cucumber $5 \%$ and banana $60 \%$ + pineapple $5 \%$ + watermelon $30 \%$ + cucumber $5 \%$ were found to be acceptable to panelists particularly with respect to aroma, colour and clarity.

\section{Acknowledgements}

Authors are grateful to staff of the Department of Food Technology, University of Ibadan, Ibadan and National Horticulture Research Institute (NIHORT), Ibadan, Nigeria for their assistance during this research work.

\section{Bibliography}

1. Swami SB., et al. "Fruit Wine Production: A Review". Journal of Food Research and Technology 2.3 (2014): 93-100.

2. Alobo AP and Offonry SU. "Characteristics of coloured wine produced from Roselle (Hibiscus sabolaritts) calyx extract". Journal of the Institute of Brewing 115.2 (2009): 91-94.

3. Chilaka CA., et al. "Evaluation of the efficiency of yeast isolates from palm wine in diverse fruit wine production". African Journal of Food Science 4.12 (2010): 764-774.

4. Jackson T and Badrie N. "Quality Changes on Storage of Caribbean Banana (Musa acuminata) Wines: Effects of Pectolase Concentration and Incubation Period". Journal of Wine Research 13.1 (2012): 43-56.

5. Awe S. "Production and microbiology of pawpaw (Carica papaya L) wine". Current Research Journal of Biological Sciences 3.5 (2011): 443-447. 
6. Mohapatra D., et al. "Post-harvest Processing of Banana: Opportunities and Challenges Food". Bioprocess Technology 4 (2011): 327-339.

7. Collins JK., et al. Sensory evaluation of low sugar watermelon by consumers". Horticulture Science 40 (2015): 883.

8. Baruwa OI. "Profitability and constraints of pineapple production in Osun State, Nigeria". Journal of Horticultural Research 21.2 (2013): 59-64.

9. Mukherjee PK. "Phytochemical and therapeutic potential of cucumber”. Fitoterapia 84 (2013): 227-236.

10. Idise OE and Odum EI. "Studies of wine produced from banana". International Journal of Biotechnology and Molecular Biology Research 2 (2013): 209-214.

11. Ogodo AC., et al. "Production of mixed fruit (pawpaw, banana and watermelon) wine using Saccharomyces cerevisiae isolated from palm wine". Springer Plus 4 (2015): 683.

12. AOAC. Official Method of Analysis. 18th ed. Association of Official Analytical Chemists, Washingt on, DC, USA (2005).

13. Daramola B and Asunni OA. "Preparation, physicochemical and sensory assessment of pawpaw-red ginger food drink". American-European Journal of Scientific Research 22 (2007): 101-105.

14. Gyamfi MA., et al. "Free radical scavenging action of medicial herbs from Ghana: thonningia sanguine on experimentally induced liver injuries". General Pharmacology 32 (1999): 661667.

15. Publido R., et al. "Antioxidant activity of dietary polyphenols as determined by a modified ferric reducing/antioxidant power assay". Journal of Agricultural and Food Chemistry 48 (2000): 3396-3402.

16. Re R., et al. "Antioxidant cavity applying an improve ABTS Radication decolourisation assay". Free Radical Biology and Medicine 26 (1999): 1231-1237.

17. Singleton VL., et al. "Analysis of total phenols and other oxidation substrates and antioxidants by means of Folin-Cioalteau Reagents". Methods in Enzymology 299 (1999): 152-178.

18. Meda A., et al. "Determination of the total phenolic, flavonoid and proline contents in Burkina Fasan honey, as well as their radical scavenging activity". Food Chemistry 91 (2005): 571577.

19. Hunt RWG and Pointer MR. "Measuring colour". John Wiley and Sons Ltd., Publication (2011).

20. Cowan I and Steel ST. “Cowan and Steel's Manual for the identification of medical bacteria". 3rd Edn. Cambridge University Press, London (2004).

21. Yamada Y., et al. "Identification of acetic acid bacteria isolated from Indonesian sources, especially of isolates classified in the genus Gluconobacter". The Journal of General and Applied Microbiology 45 (1999): 23-28.
22. Destefanis G. "The use of principal component analysis (PCA) to characterise beef". Meat science 56.3 (2000): 255259.

23. Šnirc M., et al. "Application of principal component analysis method for characterization chemical, technological, and textural parameters of farmed and pastured red deer". International Journal of Food Properties 20.4 (2017): 754-761.

24. Robinson J. The Oxford Companion to Wine (3rd Edn.), Oxford University Press, USA. (2006): 840.

25. Akubor PI., et al. "Production and evaluation of banana wine". Plant Foods for Human Nutrition 58 (2013): 1-6.

26. Ribe'reau-Gayon P. "Handbook of enology: The microbiology of wine and vinifications”. ed., John Wiley and Sons Ltd., Chichester (2006).

27. Reddy LV and Reddy OVS. "Production, optimization and characterization of wine made from mango (Mangifera indica)". Natural Product Radiance 8.4 (2009): 426-435.

28. Molina A.M., et al. "Influence of wine fermentation on the synthesis of yeast-derived volatile aroma compounds". Applied Microbiology and Biotechnology 77.3 (2007): 675-687.

29. Okafor N. "Modern industrial microbiology and biotechnology". Science publishers, Enfield, (2007): 262-278.

30. Badejo AA., et al. "Changes in Nutrient Composition, Antioxidant Properties, and Enzymes Activities of Snake Tomato (Trichosanthes cucumerina) during Ripening". Preventive Nutrition and Food Science 21.2 (2016): 9096.

31. Sun J., et al. "Antioxidants and antiproliferative activities of common fruits". Journal of Agricultural and Food Chemistry 50 (2002): 7449-7454.

32. Melo EA., et al. "Capacidade antioxidante de frutas". Journal of Pharmaceutical Sciences 44 (2008): 194-201.

33. Gawel R. "Red wine astringency: A review". Australian Journal of Grape and Wine Research 4 (1998): 74-95.

\section{Assets from publication with us}

- Prompt Acknowledgement after receiving the article

- Thorough Double blinded peer review

- Rapid Publication

- Issue of Publication Certificate

- High visibility of your Published work

Website: https://www.actascientific.com/

Submit Article: https://www.actascientific.com/submission.php Email us: editor@actascientific.com

Contact us: +919182824667 